\title{
A Case of Glottic Mucoepidermoid Carcinoma Presenting as Submucosal Mass
}

\author{
Seok Jung Hong ${ }^{1}$, Sung Hwan Lim ${ }^{1}$, Mi Ji Lee ${ }^{2}$, and Seung Woo Kim ${ }^{1}$ \\ ${ }^{1}$ Departments of Otolaryngology-Head and Neck Surgery, ${ }^{2}$ Pathology, Veterans Health Service Medical Center, Seoul, Korea
}

\section{점막하 종물 양상의 성문부 점액표피 암종 1 예}

홍석정 ${ }^{1} \cdot$ 임성환 ${ }^{1} \cdot$ 이미지 ${ }^{2} \cdot$ 김승우 $^{1}$

중앙보훈병원 이비인후과, ${ }^{1}$ 병리과 ${ }^{2}$

\author{
Received October 21, 2016 \\ Revised November 28, 2016 \\ Accepted November 28, 2016 \\ Address for correspondence \\ Seung Woo Kim, MD \\ Department of Otolaryngology- \\ Head and Neck Surgery, \\ Veterans Health Service \\ Medical Center, \\ 53 Jinhwangdo-ro 61-gil, \\ Gangdong-gu, Seoul 05368, Korea \\ Tel $+82-2-2225-1384$ \\ Fax $+82-2-2225-1385$ \\ E-mail entzzang1020@hanmail.net
}

Mucoepidermoid carcinoma (MEC) is the most common malignant tumor originated from salivary gland. However, it rarely occurs in the larynx, which is approximately less than $0.35 \%$ of all laryngeal neoplasm. In the literature, the laryngeal MEC often appears as submucosal mass with intact mucosa. As a result, most patients are diagnosed in the advanced stage due to difficulty of early detection. There is no standard treatment option because of the rarity of the disease and the prognosis varies by histological features. We recently encountered a 85 -yearold male with progressive hoarseness, and he was finally diagnosed as high grade glottic MEC. We report this rare and unique case with a literature review.

Korean J Otorhinolaryngol-Head Neck Surg 2017;60(2):90-3

Key Words Glottis · Mucoepidermoid carcinoma.

\section{서 론}

후두의 악성 종양은 대부분 편평세포 암종이 $95 \%$ 이상을 차지하고 이외에 육종, 림프종, 선암종, 흑색종, 전이암 등과 같은 비 상피성 종양이 있다. 점액표피 암종은 주로 이하선과 악하선 등의 주 타액선에서 호발하며, 후두에서의 발생은 극 히 드물어, 전체 후두암의 약 $0.35 \%$ 미만이다. ${ }^{2)}$ 후두에서 발 생하는 점액표피 암종은 영문 논문 검색에서 약 85예가 보고 되었고, ${ }^{3)}$ 국내 보고로는 성문 하부의 1 예, ${ }^{4)}$ 성문 상부의 2예 등 3예이며, ${ }^{5)}$ 성문부에 발생한 경우는 아직 보고된 바가 없다.

저자들은 애성을 주소로 내원한 85세 남자 환자에서 성문 부에 발생한 고 악성도의 점액표피 암종으로 최종 진단된 매 우 드문 증례를 경험하여 문헌고찰과 함께 보고하고자 한다.

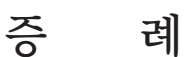

85세 남자 환자가 3 개월 전부터 시작된 진행하는 애성을 주 소로 내원하였다. 과거력상 간경화, 고혈압 및 협심증 등이 있 었다. 음주력은 주 1 회 소주 1 병 정도였고, 흡연력은 없었다. 경 성 후두내시경상에서 양측 성문부에 경계가 불분명한 미만 성 백색반이 관찰되었고, 성대 움직임은 정상이었다(Fig. 1A). 신체검사에서 구강 및 구인두에 특이 소견은 없었고, 경부 림 프절은 촉진되지 않았다. Grade, roughness, breathiness, asthenia, strain 평가법의 모든 항목에서 2점 이상이었고, 최 대 발성 시간은 2.22초로 감소하였고, 주파수 변이(jitter) 5.586 , 진폭 변이(shimmer) 12.282 및 신호대 잡음비 0.441 등으로 증가된 소견이었다. 이상의 결과를 종합하여 양측 성 대에 발생한 백반증으로 진단하고, 추가 영상학적 검사 없이, 후두미세 현미경 수술을 계획하였다. 수술 소견은 백반증이 있는 양측 진성대의 점막을 제거하였고, 최종 조직 검사 결과 
고도 이형성증으로 진단되어 외래 추적 관찰을 하였다.

첫 번째 수술 10 개월 이후 환자는 진행되는 발성 곤란과 애 성을 호소하였고, 음성학적 지표는 악화된 양상이었다. 경성 후두내시경 검사에서 성대 표면은 비교적 매끄러웠지만, 우측 성대에 종창 및 발적을 동반한 부정중위의 성대마비 소견이 관찰되었다(Fig. 1B). 성대마비의 원인을 찾기 위해 시행한 경 부 전산화단층촬영에서 우측 성문부에 약 $1.4 \times 0.8 \mathrm{~cm}$ 크기 의 갑상연골 내측막 침범이 의심되고, 비균질하게 조영 증강
되는 종물이 관찰되었다(Fig. $2 \mathrm{~A}$ and B). 양전자 방출 단층 촬영에서 우측 성문부와 성대주위 공간에 표준 섭취값 5.4 의 과대사 병변이 관찰되었고, 원격 전이의 소견은 없었다 (Fig. 2C). 이상의 소견으로 우측 성문부 악성 종양을 우선 의심 하였다. 치료 계획은 고령의 환자이고, 폐기능이 불량한 점을 고려하여, 전신마취하에 동결절편 검사로 후두 종물 확진 후, 후두 전 적출술을 시행하고자 하였으나, 환자가 완강히 거부 하였다. 확진을 위해 $\mathrm{CO}_{2}$ 레이저를 이용한 성대 절제술을 시

Fig. 1. Rigid laryngoscopic findings. It shows whitish patch on the both vocal cord at first examination (black arrows) (A). It shows edematous mucosa and paralysis on the right true vocal cord after 10 months of first laryngomicrosurgery (black arrow) (B).
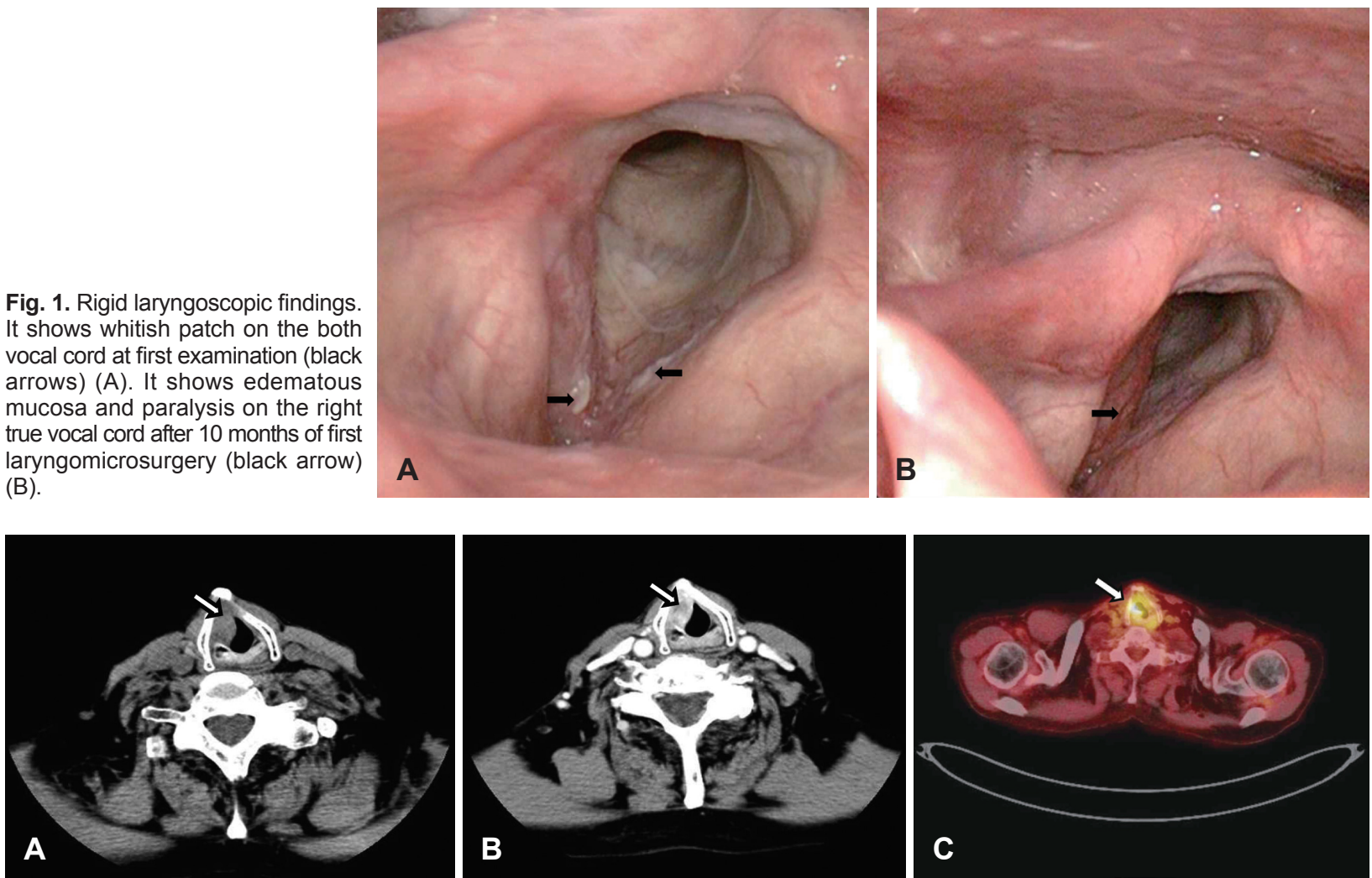

Fig. 2. Radiologic findings. The preoperative non-enhanced axial image of neck CT scans show about $1.4 \times 0.8 \mathrm{~cm}$ sized mass on right glottis (white arrow) (A) and heterogenous enhanced mass on the right glottis (white arrow) (B). The ${ }^{18} \mathrm{~F}-\mathrm{FDG}$ positron emission computed tomography scan shows strong FDG uptake on the right glottis (white arrow) and the standard uptake value is 5.4 (C). ${ }^{18}$ F-FDG:

${ }^{18}$ F-fluorodeoxyglucose, FDG: fluorodeoxyglucose.
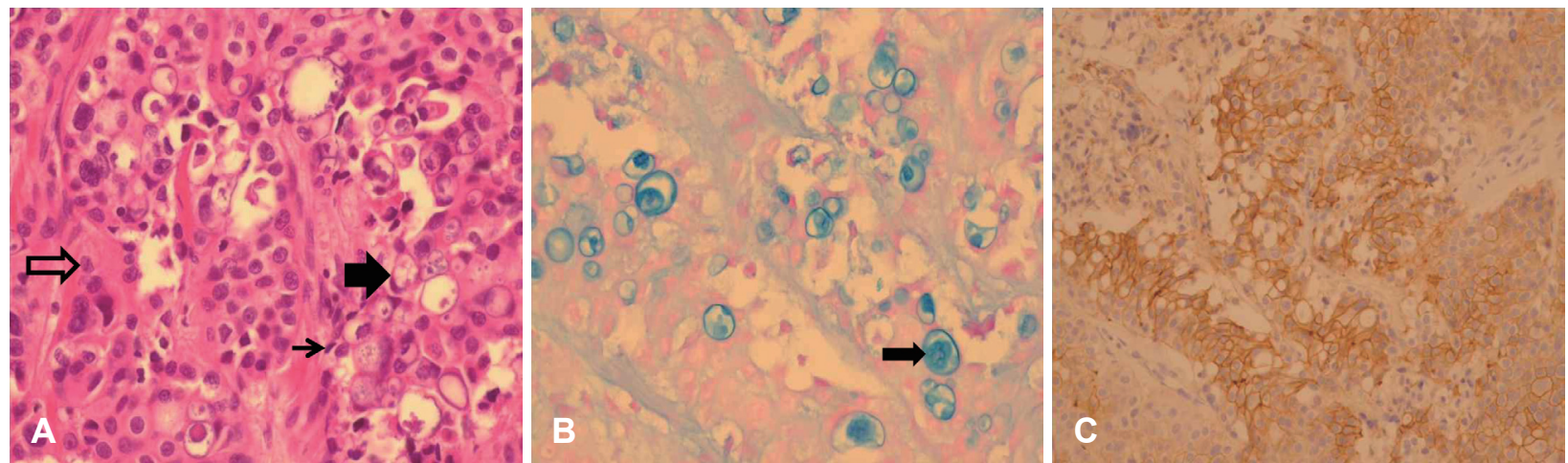

Fig. 3. Pathologic findings. The tumor consists of epidermoid cells (empty black arrow), mucus cells (narrow black arrow), and intermediate cells (large black arrow) $(\mathrm{H} \& \mathrm{E}, \times 400)(\mathrm{A})$. And intracytoplasmic mucin in mucocytes are stained bluish by alcian-blue (black arrow) $(\times 400)(B)$. Positive immunohistochemical staining for HER2 indicates high grade mucoepidermoid carcinoma $(\times 200)(C)$. 

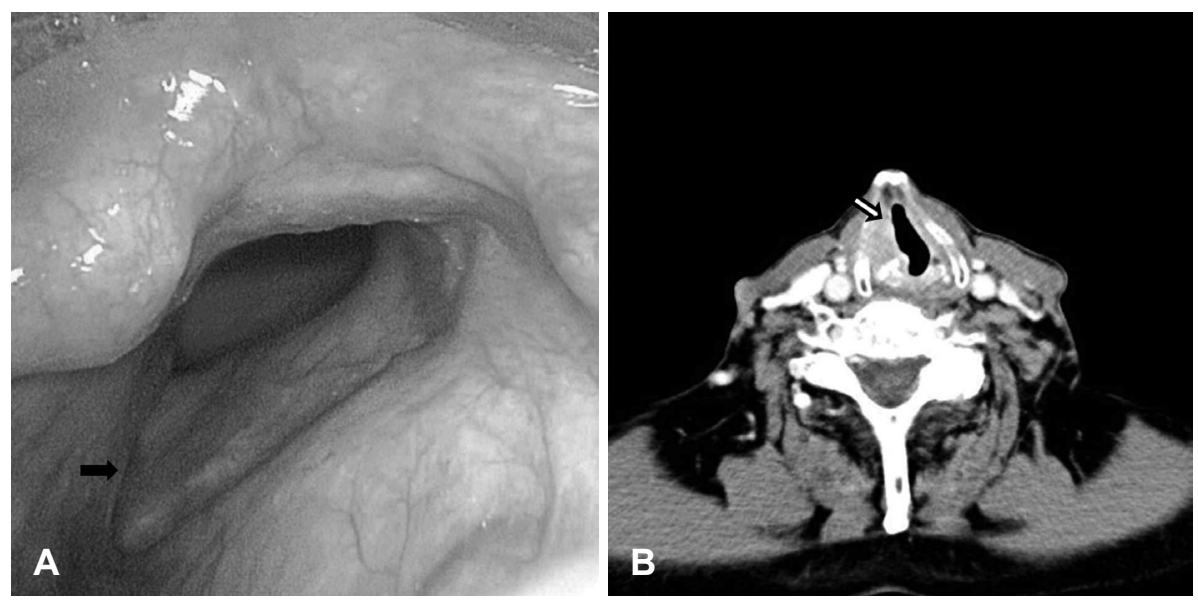

Fig. 4. Postoperative laryngoscopic and radiologic findings. It shows no definite mucosal lesion on the right glottic area (black arrow) (A). The enhanced axial image of neck CT scan shows slightly enhanced soft tissue lesion and mucosal irregularity (white arrow) (B).

행하였다. 수술 소견은 현미경하에서 종물의 경계는 전 연합, 성문하 및 갑상연골의 내측 연골막까지로 평가되었다. 3 watt 의 강도로 종물의 측방 경계에서부터 내측으로 절제하였고, 이때 다량의 출혈이 있었다. 흡인 소작기를 이용하여 지혈 후 수술을 종료하였다. 최종 병리 검사상 편평세포 양 형태의 군 집이 관찰되고 점액분비 세포가 드물며, 세포질 내 점액이 알 시안 블루 염색에 양성 소견을 보이고, HER2/neu 면역조직 화학염색상 양성 소견을 보여 고 악성도 점막표피 암종으로 최종 진단되었다(Fig. 3). 최종 병기는 pT4aNoMo로 확인되 었고, 절제 연 양성이어서, 추가 근치 수술 또는 방사선 치료 를 권유하였다. 환자는 본인의 연령 및 건강상태에 대한 염려 로 더 이상의 어떠한 치료도 거부하여 추적 관찰만 하기로 하였다. 술 후 9개월이 지난 현재까지 매월 후두내시경 검사와 3 개월마다 전산화단층촬영을 하면서 외래 추적 관찰 중이다 (Fig. 4).

\section{고 찰}

두경부 영역에서 후두암은 갑상선암 다음으로 발생 빈도가 높고 전체 악성 종양의 약 2 5\% 정도이다. ${ }^{1)}$ 대부분의 후두암 은 편평세포 암종이 95 95\%이고, 후두에 존재하는 소 타액 선에서 발생하는 암종은 $1 \%$ 미만이다. ${ }^{1,2)}$ 후두에서 발생하는 타액선 종양은 선낭 암, 점액표피 암종 등이 있고, 전자는 32 $69 \%$, 후자는 15 35\%를 차지한다. ${ }^{2,3)}$ 평균 발병 연령은 45 75 세이고, 남녀 발생 빈도는 9:1로 알려져 있다.

후두 점액표피 암종의 호발 부위는 조직학적으로 점액선이 주로 분포하는 후두실 및 가성대의 성문 상부와 전 연합부의 하연 등이다. ${ }^{3)}$ 반면에 편평세포 암종은 성문부에 가장 호발한 다. ${ }^{3,4}$ 발생 위험인자로는 편평세포 암종은 흡연, 음주 등과 관 련 있으나, 점액표피 암종의 경우는 불명확하지만, 석면, 납, 음 주, 바이러스 감염, 방사선 조사 등이 관련 있다는 보고가 있
다. ${ }^{3,5)}$ 주 증상은 편평세포 암종과 유사하게 애성, 호흡곤란 및 연하곤란 등이다. ${ }^{6}$

점액표피 암종의 조직학적 소견은 상피양 세포, 점액분비 세 포와 중간 세포 등으로 구성되며, 종양 내 낭종 형성의 정도, 신경 침윤과 괴사 유무, 세포분열 정도, 역형성 등에 따라 악 성도를 구분한다. ${ }^{6}$ 전반적으로 저 악성도 종양은 대부분 점액 분비 세포가 낭성 구조를 형성하고 유사분열이 거의 없으며, 세포의 역형성이 관찰되지 않지만, 고 악성도 종양은 상피세포 군집, 역형성 및 높은 유사분열이 등이 관찰된다. ${ }^{7)}$ 편평세포 암 종과 고 악성도 점액표피 암종은 비슷한 조직학적 특징을 보 이고 중간 세포 및 점액분비 세포의 유무가 감별하는 유일한 소견이다. ${ }^{67)}$ 고 악성도 점액표피 암종은 HER2/neu, $\mathrm{Ki}-67$ 염 색에서 양성 소견을 보이고, 나쁜 예후의 지표라고 알려져 있 다. ${ }^{8)}$ 본 증례의 경우 두 번째 수술 이후 첫 번째 병리 결과를 다시 분석한 결과 고도의 편평세포 이형성증과 함께 일부 점 액세포가 부유하는 양상이 있어서 일반적인 세포 이형성증과 는 다른 소견이 관찰되었다.

후두의 편평세포 암종은 주로 점막 표면의 융기, 궤양 및 삼 출물 소견 등이 관찰되고, 점막하 종물의 경우는 드물지만, 점액표피 암종은 점막 표면에 비교적 특이 소견이 없으며, 종 물이 점막하에서 성장하므로, 심한 애성 및 성대마비 등이 있 어야 진단되는 경우가 흔하다. 점액표피 암종의 $50 \%$ 에서 경 부 림프절 전이가 발생하고, 편평세포 암종은 원발 병소의 위 치에 따라 그 빈도가 달라지게 된다.') 예후는 저 악성도 점액표 피 암종의 5년 생존율은 92 100\%로 편평세포 암종보다 좋은 예후를 보이나, 고 악성도인 경우의 5년 생존율은 0 43\%로 편 평세포 암종보다 나쁘다. ${ }^{9}$ 그러나, 저 악성도인 경우도 종종 초기 병기에서 원격 전이를 하는 경우도 있어, 조직학적 분화 도가 완전히 예후를 반영한다고 볼 수는 없다. ${ }^{10)}$

아직 보고된 예가 적어 후두에 발생한 점액표피 암종의 치 료에 있어 확립된 방법은 없으나, 수술이 주된 치료법이며, 절 
제 연 음성이 양성 예후인자로 알려져 있다. ${ }^{11)}$ 다른 보고자는 확진된 경부 림프절 전이가 있거나 본 증례와 같이 고 악성도 인 경우 국소 재발률이 높기 때문에 술 후 방사선 치료를 권유 하였다. ${ }^{11,12)}$ 일반적으로 점액표피 암종은 편평세포 암종과 달 리 방사선 저항성이기에 방사선 치료만으로는 치료가 불충분 하지만, 초기 저 악성도인 경우 방사선 치료만으로 완치된 예도 보고되어 있다. ${ }^{13}$

본 증례의 경우 초진 시 성대 백반증 소견에만 초점을 맞추 어, 성대 점막에 대한 미세수술을 시행하였고, 이후 성문 절제 술을 통한 최종 조직 검사에서 점액표피 암종으로 진단되었 다. 후향적으로 생각해 보면, 첫 번째 내원 시 후두내시경 소 견에서 진성대의 종창 소견이 일반적인 백반증의 경우보다 심 했다고 사료된다. 또한 첫 번째 수술 이후 8 9개월 정도에 성 대마비가 발생한 것으로 추정되어, 잔존암 또는 재발암의 두 가지 가능성이 모두 있다고 사료된다. 환자는 $\mathrm{T} 4 \mathrm{a}$ 병기였지만, 후두 전 적출술 거부로 확진을 위해 부득이하게 레이저 성대 절제술을 시행하였다. 술 후 9개월까지 내시경 및 영상학적으 로 뚜렷한 재발 소견이 없지만, 국소재발 가능성이 매우 높아 서 장기적인 외래 추적 관찰이 필수적이라고 사료된다.

저자들은 이번 증례를 통해 진행하는 애성을 호소하는 고 령의 환자에서 성대 부종 및 전암성 병변이 동반된 경우 점막 하 종물로 인한 악성 병변의 가능성도 염두에 두어야 한다는 교훈을 얻었다. 이러한 경우 컴퓨터단층촬영 및 자기공명영 상 등의 영상학적 검사 및 후두 스트로보스코피 검사 등이 병 변의 조기발견에 도움이 될 수 있다고 사료된다. 비교적 단기 간의 외래 추적 관찰 기간이지만, 매우 드물고, 교훈적인 증례 로 판단되어, 본 증례를 보고하고자 한다.

\section{REFERENCES}

1) Ha JS, Woo JH, Kim DY, Chung JG. A case of sdenocarcinoma of the larynx. Korean J Otolaryngol-Head Neck Surg 2005;48(10): 1287-9.

2) Nielsen TK, Bjørndal K, Krogdahl A, Primdahl H, Kristensen CA, Andersen E, et al. Salivary gland carcinomas of the larynx: a national study in Denmark. Auris Nasus Larynx 2012;39(6):611-4.

3) Alimoglu Y, Mamanov M, Kaytaz A. High-grade mucoepidermoid carcinoma of the larynx. J Craniofac Surg 2011;22(6):e62-4.

4) Won YS, Lee MY, Lee CB, Maeng HS, Cho SH. Mucoepidermoid carcinoma of the larynx. Korean J Otolaryngol-Head Neck Surg 1986;29(6):903-7.

5) Kim JH, Roh HJ. Two cases of mucoepidermoid carcinma of the larynx. J Clin Otolaryngol Head Neck Surg 1994;5(2):376-81.

6) Calis AB, Coskun BU, Seven H, Sayin I, Basak T. Laryngeal mucoepidermoid carcinoma: report of two cases. Auris Nasus Larynx 2006;33(2):211-4.

7) Mokhtari S, Mokhtari S. Clinical features and differential diagnoses in laryngeal mucoepidermoid carcinoma. Clin Med Insights Pathol 2012;5:1-6.

8) Nguyen LH, Black MJ, Hier M, Chauvin P, Rochon L. HER2/neu and $\mathrm{Ki}-67$ as prognostic indicators in mucoepidermoid carcinoma of salivary glands. J Otolaryngol 2003;32(5):328-31.

9) Pires FR, de Almeida OP, de Araújo VC, Kowalski LP. Prognostic factors in head and neck mucoepidermoid carcinoma. Arch Otolaryngol Head Neck Surg 2004;130(2):174-80.

10) Ozawa H, Tomita T, Sakamoto K, Tagawa T, Fujii R, Kanzaki S, et al. Mucoepidermoid carcinoma of the head and neck: clinical analysis of 43 patients. Jpn J Clin Oncol 2008;38(6):414-8.

11) Prgomet D, Bilić M, Bumber Z, Manojlović S, Katić V. Mucoepidermoid carcinoma of the larynx: report of three cases. J Laryngol Otol 2003; 117(12):998-1000

12) Tanaka H, Kohno A, Kawabata K, Sato Y. Mucoepidermoid carcinoma of an adolescent epiglottis. Jpn J Radiol 2010;28(9):692-4.

13) Shonai T, Hareyama M, Sakata K, Oouchi A, Nagakura H, Koito K, et al. Mucoepidermoid carcinoma of the larynx: a case which responded completely to radiotherapy and a review of the literature. Jpn J Clin Oncol 1998;28(5):339-42. 